Article

\title{
Genetic and Phenotypic Analyses of a Papaver somniferum T-DNA Insertional Mutant with Altered Alkaloid Composition
}

\author{
Noriaki Kawano $^{1{ }^{1 *} \text {, Fumiyuki Kiuchi }}{ }^{2}$, Nobuo Kawahara ${ }^{1}$ and Kayo Yoshimatsu ${ }^{1}$
}

1 Division of Tsukuba, Research Center for Medicinal Plant Resources, National Institute of Biomedical Innovation, 1-2 Hachimandai, Tsukuba, Ibaraki 305-0843, Japan;

E-Mails: kawahara@nibio.go.jp (N.K.); yoshimat@nibio.go.jp (K.Y.)

2 Faculty of Pharmacy, Keio University, 1-5-30 Shibakoen, Minato-ku, Tokyo 105-8512, Japan; E-Mail: kiuchi-fm@pha.keio.ac.jp

* Author to whom correspondence should be addressed; E-Mail: nkawano@nibio.go.jp; Tel.: +81-29-838-0571; Fax: +81-29-838-0575.

Received: 29 November 2011; in revised form: 15 January 2012 / Accepted: 17 January 2012 / Published: 2 February 2012

\begin{abstract}
The in vitro shoot culture of a T-DNA insertional mutant of Papaver somniferum L. established by the infection of Agrobacterium rhizogenes MAFF03-01724 accumulated thebaine instead of morphine as a major opium alkaloid. To develop a non-narcotic opium poppy and to gain insight into its genetic background, we have transplanted this mutant to soil, and analyzed its alkaloid content along with the manner of inheritance of T-DNA insertion loci among its selfed progenies. In the transplanted $\mathrm{T}_{0}$ primary mutant, the opium (latex) was found to be rich in thebaine (16.3\% of dried opium) by HPLC analysis. The analyses on T-DNA insertion loci by inverse PCR, adaptor-ligation PCR, and quantitative real-time PCR revealed that as many as 18 copies of T-DNAs were integrated into a poppy genome in a highly complicated manner. The number of copies of T-DNAs was decreased to seven in the selected $T_{3}$ progenies, in which the average thebaine content was 2.4-fold that of the wild type plant. This may indicate that the high thebaine phenotype was increasingly stabilized as the number of T-DNA copies was decreased. In addition, by reverse transcription PCR analysis on selected morphine biosynthetic genes, the expression of codeine 6-O-demethylase was clearly shown to be diminished in the $\mathrm{T}_{0}$ in vitro shoot culture, which can be considered as one of the key factors of altered alkaloid composition.
\end{abstract}


Keywords: Papaver somniferum L.; opium alkaloid; Agrobacterium rhizogenes; T-DNA insertional mutant

\section{Introduction}

Many attempts have been made to use breeding or molecular biological methods to modify the ability to produce secondary metabolites in medicinal plants. Among the challenges being addressed, manipulations of the morphine biosynthesis in the opium poppy (Papaver somniferum L.), particularly the conversion of narcotic morphine to codeine, which is of high importance as an antitussive and a synthetic source of dihydrocodeine, or to thebaine, which is also an important starting material for the semi-synthesis of the analgesic oxycodone, will contribute to the control of narcotics, and to the supply of useful alkaloids for the production of pharmaceuticals.

The gradual elucidation of enzymology of the alkaloid biosynthesis in $P$. somniferum led to genetical engineering of alkaloid biosynthetic pathway using native genes. The first report was on the introduction of a gene encoding berberine bridge enzyme (BBE) to $P$. somniferum in antisense orientation [1]. To date, several reports on metabolic engineering of $P$. somniferum have appeared, such as RNAi-mediated gene silencing of codeinone reductase (COR) [2], overexpression of COR [3], overexpression and antisense co-suppression of ( $S$ - $N$-methylcoclaurine-3'-hydroxylase (CYP80B3) [4], overexpression and RNAi-mediated gene silencing of salutaridinol-7- $O$-acetyltransferase (SalAT) [5], and RNAi-mediated gene silencing of SalAT [6]. Mutant poppy top1 [7] which accumulates thebaine and oripavine as major alkaloids instead of morphine was also established by the treatment of mutagen (ethyl methanesulphonate) and screening of progeny plants.

The T-DNA insertional mutant clone of $P$. somniferum PsM1-2, which we developed by the infection of the Agrobacterium rhizogenes strain MAFF03-01724, regenerated shoots from embryogenic callus that lacked the ability to produce morphine. Codeine was detected as a major alkaloid in this in vitro shoot culture [8]. By the improvement of the alkaloid analysis and proceeding studies on this mutant, thebaine ( $c a .55 \mu \mathrm{g} / \mathrm{g}$ dry weight) and codeine ( $c a .20 \mu \mathrm{g} / \mathrm{g}$ dry weight) were found to be the major opium alkaloids in the in vitro regenerated shoots [9]. The information provided from this mutant, which shows an altered alkaloid composition, might make an important contribution to the further modification of alkaloid production in P. somniferum, and therefore we carried out genetic and phenotypic analyses on this mutant.

Recently, long unidentified enzymes involved in the two demethylation steps in the conversion of thebaine to morphine were successfully identified as non-heme dioxygenases [10]. These two enzymes, namely, thebaine 6- $O$-demethylase (T6ODM) and codeine $O$-demethylase (CODM), represent the first known 2-oxoglutarate/Fe(II)-dependent dioxygenases that catalyze $O$-demethylation. The altered alkaloid composition in the PsM1-2 mutant may be due to the genetic mutation in the conversion steps from thebaine to morphine. In the present study, an expression analysis of these two enzymes together with selected genes involved in the morphine biosynthesis was carried out to reveal the molecular mechanism of the mutation. 


\section{Results and Discussion}

\subsection{Morphological Characteristics of the PsM1-2 Mutants}

The days to flowering, number of petals, appearance of split on the boundary of the petal, and height of the aerial part at the seed-filling stage of soil-cultivated $\mathrm{T}_{0}$ mutant and selfed progenies are summarized in Table 1 . The $\mathrm{T}_{0}$ primary mutant showed delay of flowering and dwarfness. In addition, a deep split was observed on the boundary of the petal (Figure 1). Delay of flowering was consistantly observed in the progenies. The number of petals, which was not altered at the $T_{0}$, varied in the $T_{1}, T_{2}$ and $\mathrm{T}_{3}$ progenies. A deep split at the boundary of the petal was observed in $45 \%$ of $\mathrm{T}_{1}$ plants, $33 \%$ to $83 \%$ of $\mathrm{T}_{2}$ plants, and $8.3 \%$ and $10 \%$ of $\mathrm{T}_{3}$ plants.

Table 1. Summary of the morphological characteristics of PsM1-2 $T_{0}$ mutant, selfed progenies, and WT plant.

\begin{tabular}{|c|c|c|c|c|c|c|}
\hline Progenies & Lines & $\begin{array}{l}\text { Number } \\
\text { of Plants }\end{array}$ & $\begin{array}{l}\text { Days to Flowering } \\
\text { (Mean } \pm \text { SD) } \\
\text { (days) }\end{array}$ & $\begin{array}{l}\text { Number of Petals: } \\
\text { Percentage (\%) }\end{array}$ & $\begin{array}{l}\text { Split on } \\
\text { Petal } \\
\text { Boundary } \\
(\%) \\
\end{array}$ & $\begin{array}{l}\text { Plant Height } \\
\text { (Aerial Part) } \\
(\text { Mean } \pm \text { SD) } \\
(\mathrm{cm}) \\
\end{array}$ \\
\hline \multirow{2}{*}{$\mathrm{T}_{0}$} & WT & 1 & $47 * 1$ & 4: 100 & 0 & 60.0 \\
\hline & $\mathrm{T}_{0}$ & 1 & $71 * 1$ & 4: 100 & 100 & 38.0 \\
\hline \multirow[b]{2}{*}{$\mathrm{T}_{1}$} & WT & 6 & $53.5 \pm 4.8$ & 4: 100 & 0 & $42.4 \pm 5.8$ \\
\hline & $\mathrm{T}_{1}$ & 60 & $100.6 \pm 14.6$ & $\begin{array}{l}3: 1.7,4: 41.7,5: 35.0 \\
6: 16.7,7: 3.3,8: 1.7\end{array}$ & 45.0 & $52.1 \pm 8.5^{\# \#}$ \\
\hline \multirow{5}{*}{$\mathrm{T}_{2}$} & WT & 12 & $53.3 \pm 4.0$ & $3: 25.0,4: 75.0$ & 8.3 & $36.0 \pm 7.6$ \\
\hline & $\# 1-27(\mathrm{HT})$ & 15 & $90.8 \pm 12.6$ & $\begin{array}{l}5: 60.0,6: 33.3 \\
10: 6.7\end{array}$ & 60.0 & $44.7 \pm 5.4^{\# \#}$ \\
\hline & \#2-17(HT) & 6 & $79.8 \pm 2.5^{\# \# \# \#}$ & $\begin{array}{l}5: 50.0,6: 33.3 \\
8: 16.7\end{array}$ & 83.3 & $45.1 \pm 3.4^{\#}$ \\
\hline & \#2-1(LT) & 12 & 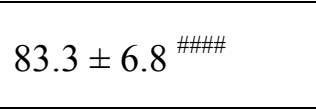 & $\begin{array}{l}5: 66.7,6: 16.7 \\
7: 8.3,8: 8.3 \\
\end{array}$ & 33.3 & $35.6 \pm 7.8$ \\
\hline & \#2-6(LT) & 10 & 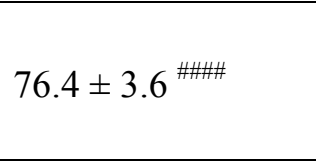 & $\begin{array}{l}5: 10.0,6: 40.0, \\
7: 30.0,8: 10.0, \\
12: 10.0\end{array}$ & 80.0 & $39.4 \pm 3.1$ \\
\hline \multirow{3}{*}{$\mathrm{T}_{3}$} & WT & 6 & $109.4 \pm 0.9^{* 2}$ & $4: 100$ & 0 & $80.3 \pm 5.8$ \\
\hline & $\begin{array}{l}\# 1-27(\mathrm{HT}) \\
\mathrm{L} \# 2\end{array}$ & 10 & $129.2 \pm 11.9 *^{3}, \ldots \#$ & $\begin{array}{l}4: 40.0,5: 50.0 \\
6: 10.0\end{array}$ & 10.0 & $45.8 \pm 7.9^{\# \# \#}$ \\
\hline & $\begin{array}{l}\# 2-17(\mathrm{HT}) \\
\# 2-1\end{array}$ & 12 & $131.1 \pm 7.3 * 4, \ldots \# \#$ & $3: 8.3,4: 75.0,5: 16.7$ & 8.3 & $47.0 \pm 13.4$ \\
\hline
\end{tabular}

${ }^{* 1}$ : Days after transplanting; ${ }^{* 2}: \mathrm{n}=5 ; *^{3}: \mathrm{n}=9 ; *^{* 4}: \mathrm{n}=11 ;{ }^{\#} p<0.05 ;{ }^{\# \#} p<0.01 ;{ }^{\# \#} p<0.005 ;$ and \#\#\#\# $p 0.001$ vs. WT.

\subsection{Alkaloid Composition in the PsM1-2 Mutants}

The soil-cultivated PsM1-2 $\mathrm{T}_{0}$ primary mutant accumulated $16.3 \%$ ( $\%$ dry weight $)$ of thebaine as a major opium alkaloid in the latex, which was not detected in the WT (Figure 2; Table 2). The 
morphine content in the mutant was $1.3 \%$, which was $c a$. one tenth of that in the WT, and the codeine content was $4.2 \%$ in the mutant, vs. $1.3 \%$ in the WT.

Figure 1. Appearances of the PsM1-2 $\mathrm{T}_{0}$ primary mutant and WT P. somniferum soil-cultivated in the phytotron. (A) WT, (B) PsM1-2 $\mathrm{T}_{0}$. Upper left: flower; right: grown plant; bottom left: petals with deep splits (PsM1-2 $\mathrm{T}_{0}$ only).

(A) WT

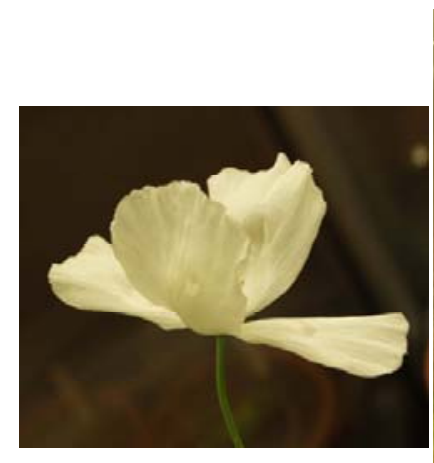

(B) PsM1-2 $\mathrm{T}_{0}$

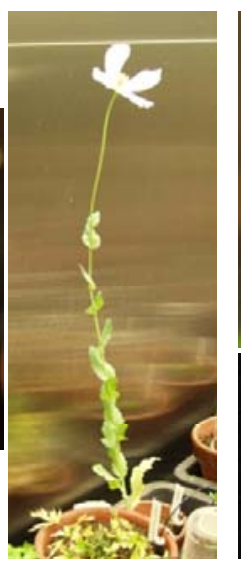

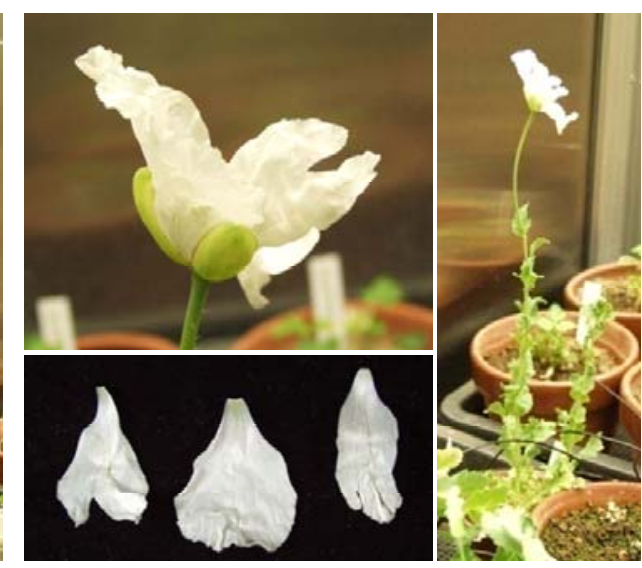

Figure 2. Alkaloid content in the latex from the soil-cultivated WT and PsM1-2 $\mathrm{T}_{0}$ mutant. nd: Not detected.

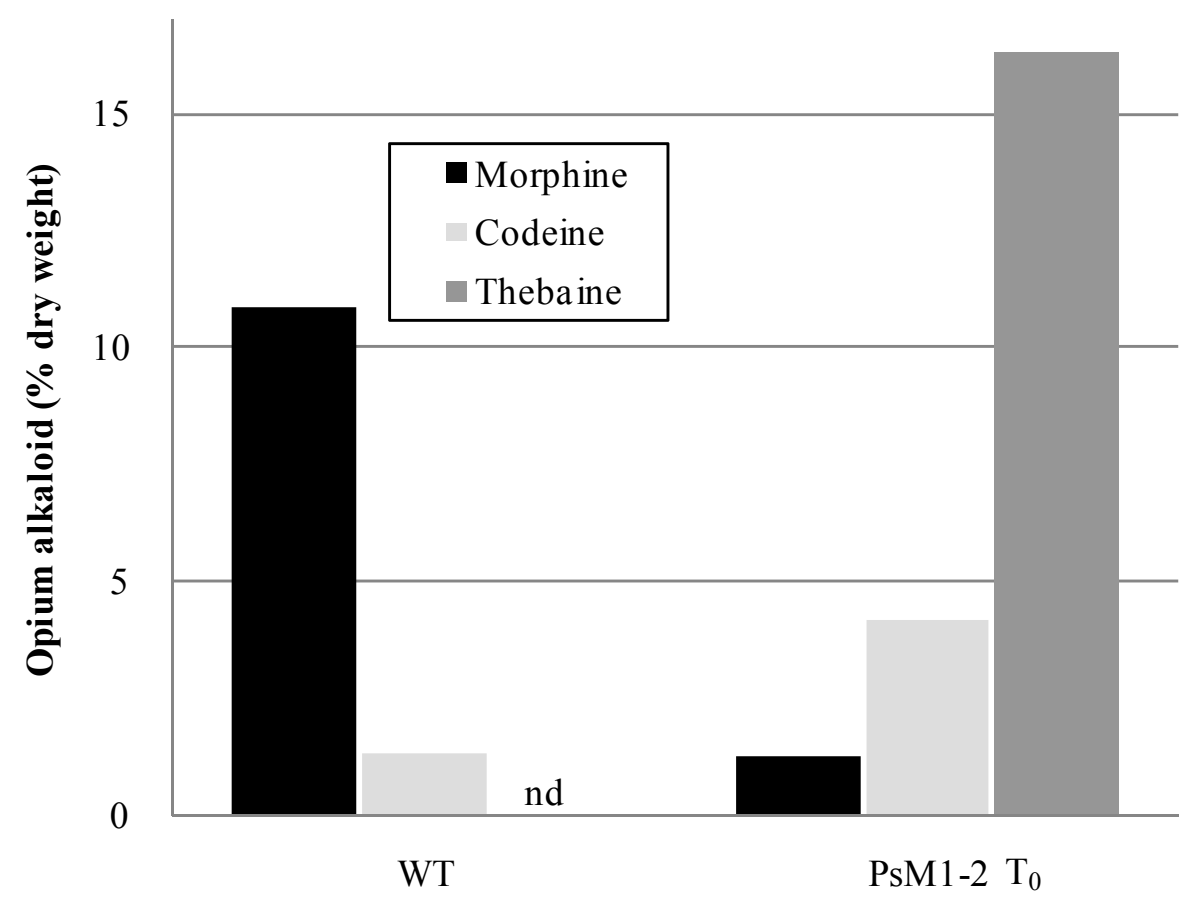

The alkaloid compositions in the dried opium of selected progenies are summarized in Table 2, and the morphine and thebaine contents of the $T_{1}, T_{2}$ and $T_{3}$ plants are plotted on a scatter diagram (Figure 3 ). The HPLC chromatograms of the representative lines of the $\mathrm{T}_{1}$ plants, WT plant, and authentic standards are shown in the Supplementary Figure 1. 
Table 2. Opium alkaloid contents in PsM1-2 $\mathrm{T}_{0}$ mutant and selfed progenies.

\begin{tabular}{|c|c|c|c|c|c|c|c|}
\hline Progenies & Lines & $\begin{array}{l}\text { Number } \\
\text { of plants }\end{array}$ & Morphine & Codeine & Thebaine & Papaverine & Noscapine \\
\hline \multirow{2}{*}{$\mathrm{T}_{0}$} & WT & 1 & 10.9 & 1.3 & nd * & 2.0 & 9.2 \\
\hline & $\mathrm{T}_{0}$ & 1 & 1.3 & 4.2 & 16.3 & 2.3 & 10.2 \\
\hline \multirow{2}{*}{$\mathrm{T}_{1}$} & WT & 6 & $11.2 \pm 4.0$ & $2.6 \pm 2.1$ & $0.3 \pm 0.2$ & $2.4 \pm 0.7$ & $11.6 \pm 4.3$ \\
\hline & $\mathrm{T}_{1}$ & 60 & $6.3 \pm 4.6^{\#}$ & $3.8 \pm 1.5$ & $11.1 \pm 6.1$ & $1.6 \pm 0.5$ & $7.9 \pm 2.1 \mathrm{\# \#}$ \\
\hline \multirow{4}{*}{$\begin{array}{l}\text { Selected } \\
\text { lines }\left(T_{1}\right)\end{array}$} & $\# 1-27(\mathrm{HT})$ & - & 4.3 & 5.1 & 23.1 & 2.3 & 7.2 \\
\hline & \#2-17(HT) & - & 5.5 & 3.7 & 24.4 & 1.9 & 6.8 \\
\hline & $\# 2-1(\mathrm{LT})$ & - & 23.0 & 1.3 & 0.3 & 1.8 & 8.4 \\
\hline & $\# 2-6(\mathrm{LT})$ & - & 13.6 & 2.1 & 1.0 & 1.5 & 6.9 \\
\hline \multirow{5}{*}{$\mathrm{T}_{2}$} & WT & 11 & $18.4 \pm 3.3$ & $1.5 \pm 0.9$ & $0.4 \pm 0.2$ & $2.7 \pm 1.0$ & $18.4 \pm 4.3$ \\
\hline & $\# 1-27(\mathrm{HT})$ & 15 & $7.0 \pm 4.1^{\# \#}$ & $5.8 \pm 1.6^{\# \#}$ & $19.1 \pm 7.3^{\# \#}$ & $2.2 \pm 0.4$ & $9.6 \pm 2.4^{\# \#}$ \\
\hline & \#2-17(HT) & 6 & $9.8 \pm 8.1^{\#}$ & $6.0 \pm 0.5^{\text {\#\# }}$ & $14.5 \pm 6.1 \ldots$ & $3.0 \pm 0.4$ & $9.2 \pm 1.7^{\# \#}$ \\
\hline & $\# 2-1(\mathrm{LT})$ & 12 & $7.6 \pm 3.3^{\# \#}$ & $5.8 \pm 1.1^{\# \#}$ & $15.9 \pm 7.2^{\# \# \#}$ & $2.8 \pm 0.8$ & $8.0 \pm 2.0^{\# \# \#}$ \\
\hline & $\# 2-6(\mathrm{LT})$ & 10 & $7.6 \pm 6.8^{\# \#}$ & $4.6 \pm 1.3^{\# \#}$ & 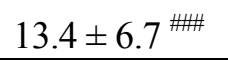 & $2.7 \pm 0.5$ & $11.7 \pm 2.7^{\# \#}$ \\
\hline \multirow{4}{*}{$\begin{array}{l}\text { Selected } \\
\text { lines }\left(T_{2}\right)\end{array}$} & $\begin{array}{l}\# 1-27(\mathrm{HT}) \\
\mathrm{L} \# 2\end{array}$ & - & 4.9 & 6.1 & 29.6 & 2.4 & 9.4 \\
\hline & $\begin{array}{l}\# 2-17(\mathrm{HT}) \\
\# 2-1\end{array}$ & - & 3.7 & 6.5 & 20.0 & 3.1 & 10.4 \\
\hline & $\begin{array}{l}\# 2-1(\mathrm{LT}) \\
\# 2-4\end{array}$ & - & 5.3 & 4.3 & 29.4 & 3.1 & 9.1 \\
\hline & $\begin{array}{l}\# 2-6(\mathrm{LT}) \\
\# 2-2\end{array}$ & - & 3.1 & 4.9 & 21.1 & 2.7 & 13.2 \\
\hline \multirow{3}{*}{$\mathrm{T}_{3}$} & WT & 6 & $11.1 \pm 4.1$ & $1.5 \pm 0.5$ & $3.3 \pm 2.1$ & $1.9 \pm 0.5$ & $4.2 \pm 1.6$ \\
\hline & $\begin{array}{l}\# 1-27(\mathrm{HT}) \\
\mathrm{L} \# 2\end{array}$ & 10 & $2.5 \pm 0.6^{\# \#}$ & 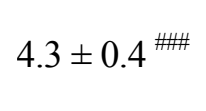 & $7.7 \pm 1.9^{\# \#}$ & 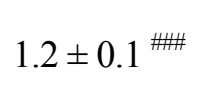 & $5.1 \pm 0.7$ \\
\hline & $\begin{array}{l}\# 2-17(\mathrm{HT}) \\
\# 2-1\end{array}$ & 12 & $1.8 \pm 0.5^{\mathrm{m}}$ & $2.9 \pm 0.5^{\text {\#叫 }}$ & $8.1 \pm 2.3^{\text {\#\# }}$ & 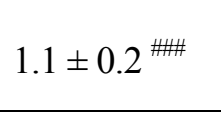 & $4.1 \pm 0.8$ \\
\hline
\end{tabular}

Mean value of the alkaloid content ( $\%$ dry weight) with standard deviation (mean $\pm \mathrm{SD}$ ) for each line and the alkaloid content of selected lines are summarized. nd *: Not detected; ${ }^{\#} p<0.05 ;{ }^{\#} p<0.005$; and ${ }^{\# \#} p<0.001 v s$. WT.

The thebaine content in $\mathrm{T}_{1}$ plants varied widely, from $0.3 \%$ to $26.5 \%$. From these plants, two high thebaine lines, \#1-27(HT) (thebaine content: 23.1\%) and \#2-17(HT) (24.4\%), and two low thebaine lines, \#2-1(LT) (0.3\%) and \#2-6(LT) (1.0\%), were selected and subjected to analysis of the $\mathrm{T}_{2}$ progeny. Interestingly, most of the progeny plants from both the HT and LT lines showed the high thebaine phenotype. From the $\mathrm{T}_{2}$ lines, two lines, \#1-27(HT)L\#2 (thebaine content: $29.6 \%$ ) and \#2-17(HT)\#2-1 $(20.0 \%)$, were selected for the analysis of $\mathrm{T}_{3}$ progeny.

The thebaine content in $\mathrm{T}_{3}$ plants ranged from $4.2 \%$ to $10.0 \%$ in \#1-27(HT)L\#2 and from $3.7 \%$ to $10.9 \%$ in $\# 2-17$ (HT)\#2-1. The average thebaine content in $\mathrm{T}_{3}$ plants (two lines combined) was 2.4-fold of that in the WT; in contrast, the average morphine content decreased to ca. one fifth of that in the WT (Figure 4). 
Figure 3. Alkaloid content in the latex from the soil-cultivated WT and PsM1-2 $\mathrm{T}_{0}$ mutant. nd: Not detected. Scatter diagram of the morphine (x-axis) and thebaine (y-axis) contents in (A) PsM1-2 T 1 plants $(n=60)$ and WT plants $(n=6),(\mathbf{B})$ four lines of PsM1-2 T2 plants and WT plants, and (C) two lines of PsM1-2 $\mathrm{T}_{3}$ plants and WT plants.
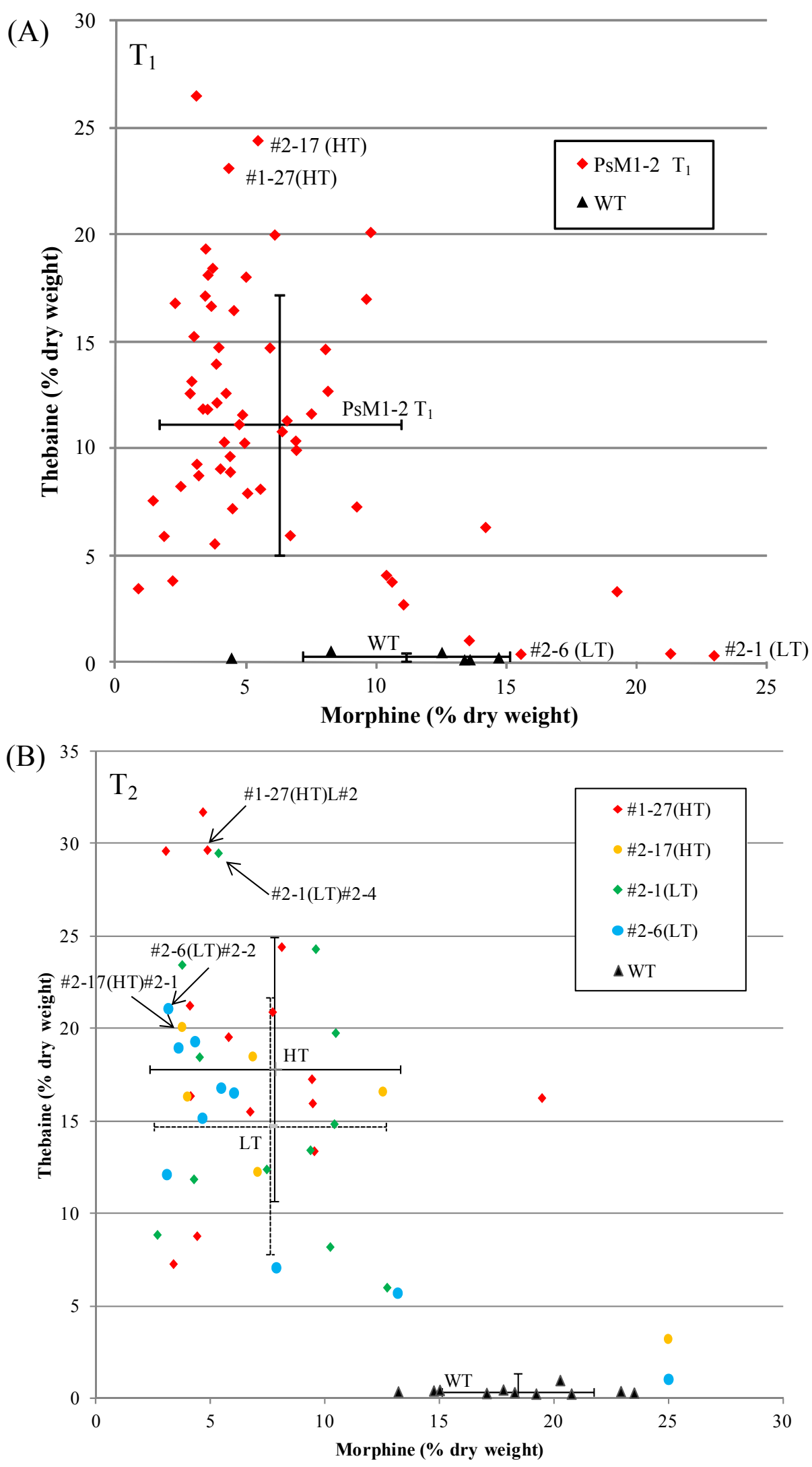
Figure 3. Cont.

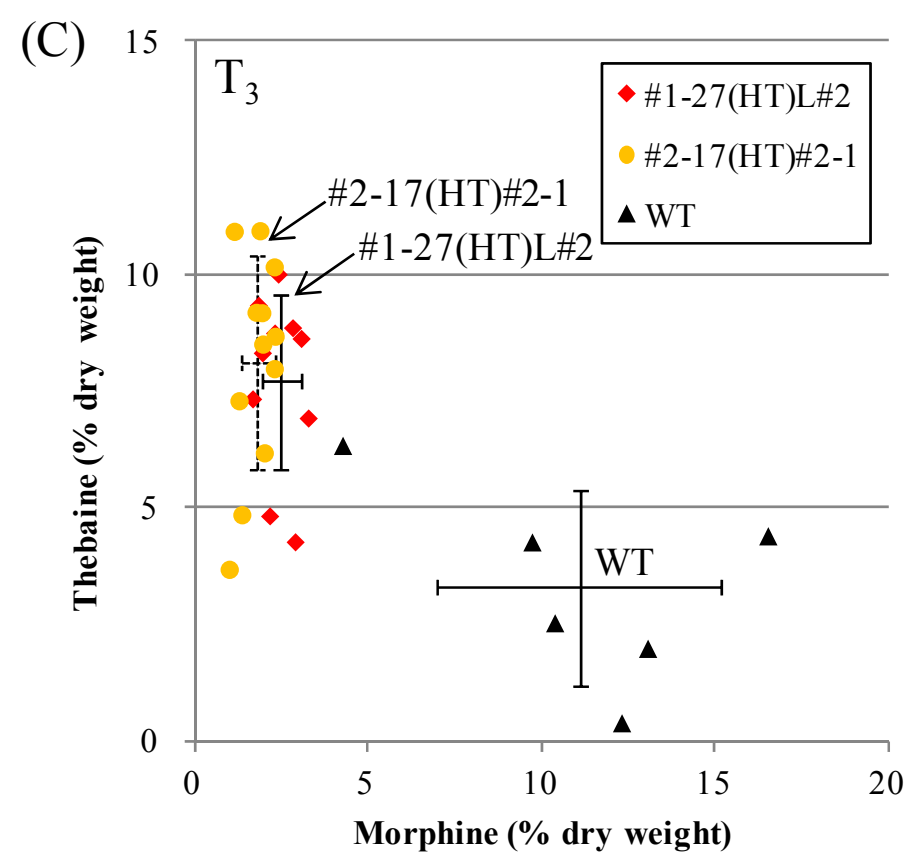

Crossed bars indicate the mean value (crossed point) and standard deviations for morphine (horizontal bar) and thebaine (vertical bar) contents in (A) PsM1-2 $\mathrm{T}_{1}$ plants and WT plants, (B) HT (\#1-27 and \#2-17 were combined) and LT (\#2-1 and \#2-6 were combined, dotted) lines, and (C) WT, \#1-27(HT)L\#2, and \#2-17(HT)\#2-1 (dotted) plant lines. (A) Lines \#1-27(high thebaine, HT), \#2-17(HT), \#2-1(low thebaine, LT), and \#2-6(LT) were used for analyses on $\mathrm{T}_{2}$ progeny. (B) Lines \#1-27(HT)L\#2 and \#2-17(HT)\#2-1 were used for analyses on $\mathrm{T}_{3}$ progeny.

Figure 4. Morphine, codeine, and thebaine contents in $T_{3}$ progeny. Mean value of six (WT), 10 [\#1-27(HT)L\#2], and 12 [\#2-17(HT)\#2-1] plants. Bars indicate standard deviation. $* p<0.005$ and $* * p<0.001$ vs. WT.

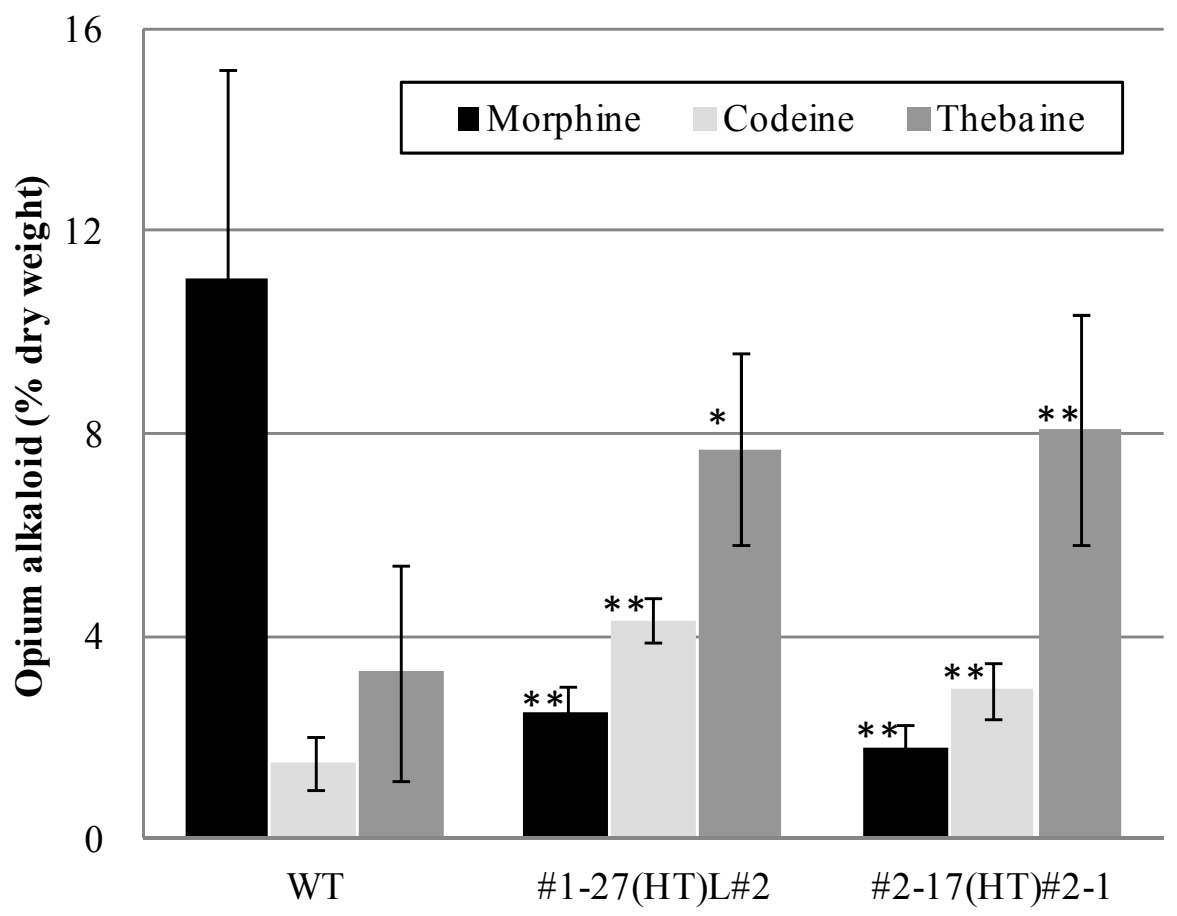




\subsection{T-DNA Insertion Loci Analysis by IPCR and AL-PCR}

The genomic DNA regions adjacent to the inserted T-DNA borders were analyzed by the IPCR and AL-PCR methods. The obtained DNA fragments are summarized in Supplementary Table 1 and Figure 5 along with the PCR methods, the combination of template circular or adaptor-ligated genome DNA libraries, and the primer sets. Sequence analysis of the amplified products revealed that the fragments were classified into three types, (A) T-DNAs connected with $P$. somniferum genome DNA, (B) T-DNAs connected in tandem, and (C) T-DNAs connected with T-DNA internal fragments, as shown in Figure 5.

Type (A) includes four types of genome DNA fragments adjacent to T-DNA LB, and six types of genome DNA fragments adjacent to T-DNA RB. Of these fragments, LB1g and RB2g, LB3g and RB6g were confirmed to be both ends of single genomic loci, by PCR over the LB and RB genomic regions. Although the tally of paired border for other fragments were not found, at least eight independent T-DNA integrated sites, namely RB1, RB2 (LB1-RB2), RB3, RB4, RB5, LB2, LB3 (LB3-RB6), and LB4 were estimated to exist in the $\mathrm{T}_{0}$ plant.

A DNA fragment homologous (59\% identity at the amino acid level) to the WRKY4 transcription factor (DDBJ/EMBL/GenBank accession no. AF425835) from A. thaliana was found in the LB1g region, at 695-952 bp 5' upstream of the junction. The DNA sequence of LB1g, which included a WRKY-like gene, was deposited in the DDBJ/EMBL/GenBank under accession No. AB574419.

No other gene with significant homology was found by the BLAST search tool in the genomic DNA regions adjacent to the inserted T-DNA.

Figure 5. Schematic diagram of amplified fragments obtained in the analyses of T-DNA insertion loci in $\mathrm{T}_{0}$. (A) T-DNAs connected with P.somniferum genome (10 types, eight sites), (B) T-DNAs connected in tandem (six types), (C) T-DNAs connected with orf13 fragments (four types).

(A)

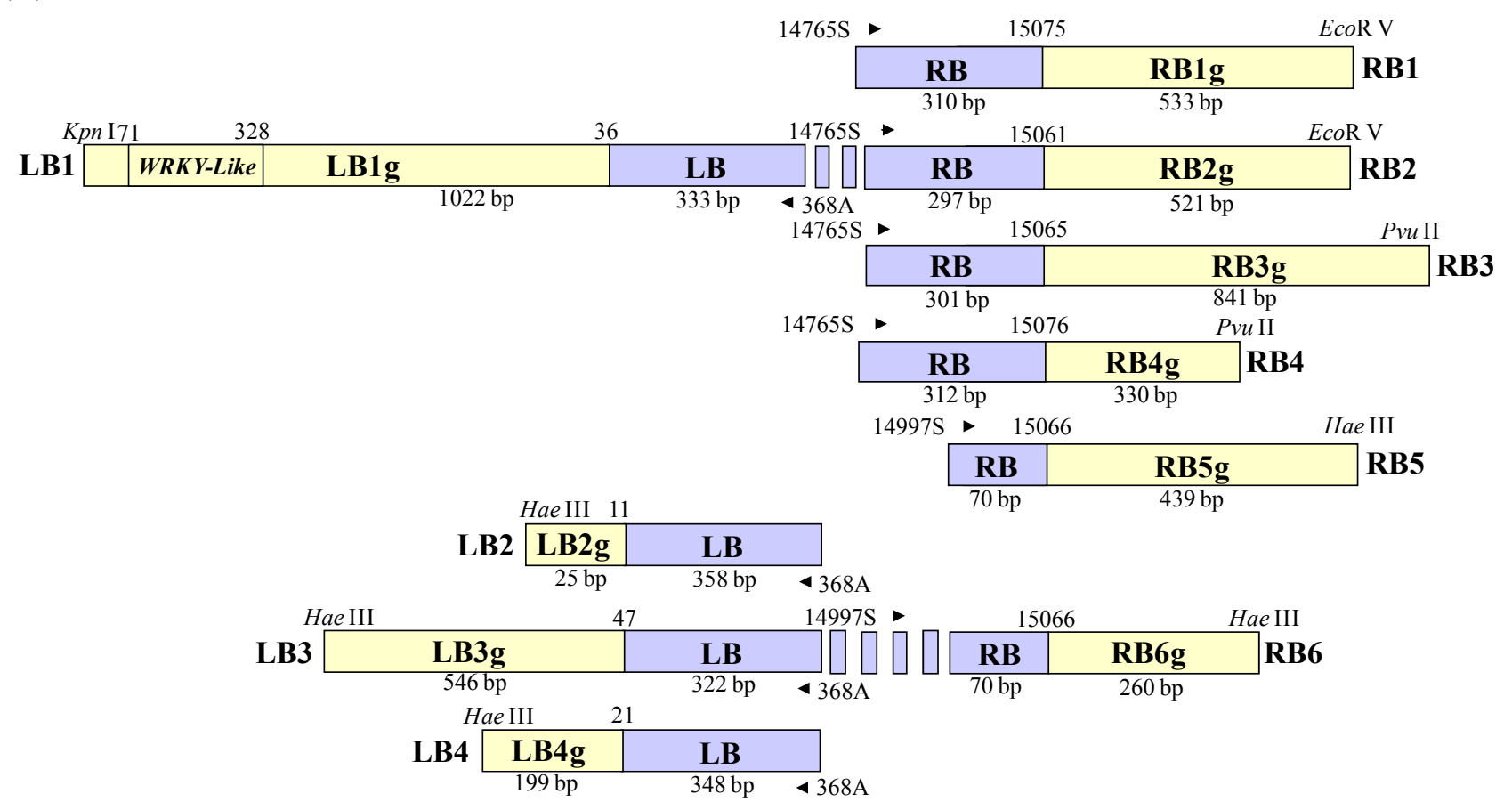


Figure 5. Cont.

(B)
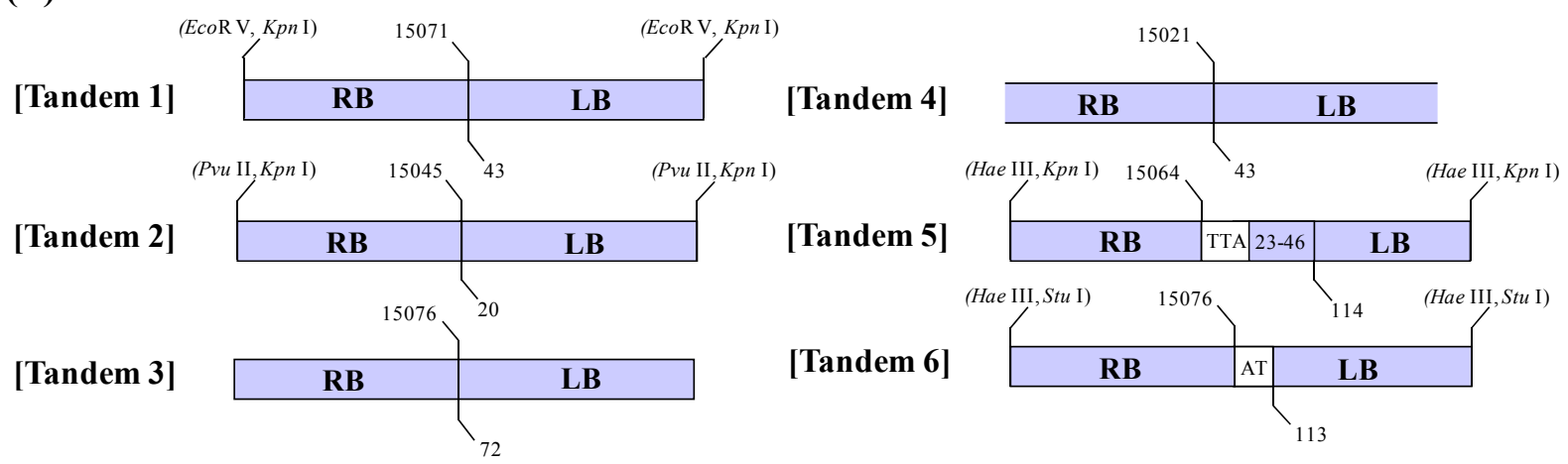

(C)
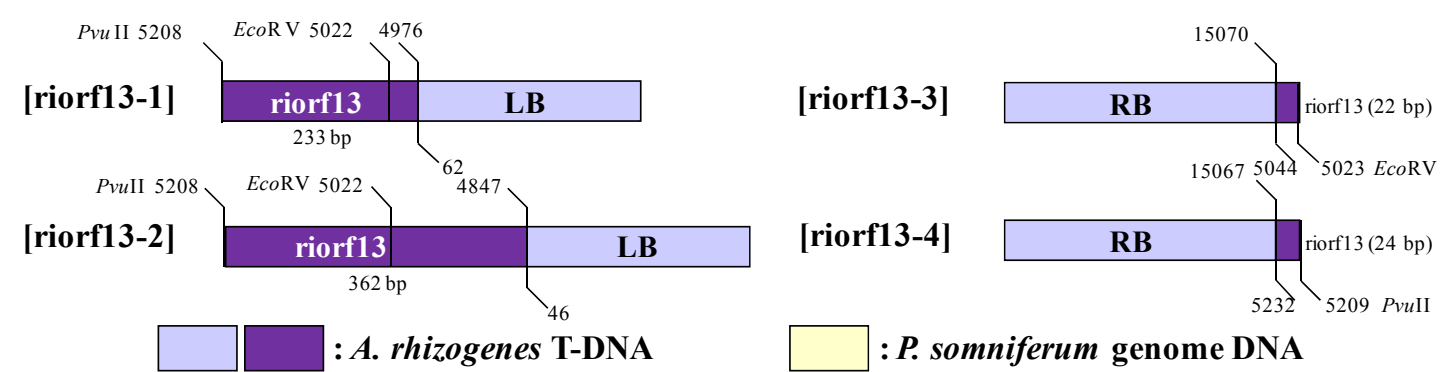

Numbers correspond to the nucleotide positions in the T-DNA. Names of restriction enzymes used for the library construction and primers used for PCR are also shown. Fragment names with "g" indicate the fragments derived from the $P$. somniferum genome DNA. LB and RB correspond to the left and right border of T-DNA, respectively. Fragment "TTA" and " $23-46$ " found in: "Tandem 5" were three nucleotide TTA and the complementary $24 \mathrm{bp}$ sequence of the T-DNA left border (nucleotide number 23 to 46). Fragment "AT" found in "Tandem 6" was two bp nucleotides. "Riorf13" is the partial T-DNA fragment annotated as riorf13.

Type (B) includes six types of DNA fragments. RB and LB were connected in a tail-to head manner at different junctions, or short DNA fragments were sandwiched. The fragment "Tandem 3" was found only in the genome direct amplification of T-DNA borders.

Type (C) consists of four DNA fragments. Two of the fragments were made up of short partial fragments of T-DNA riorf13 attached to an $\mathrm{LB}$, and the other two were made up of RB attached to a fragment of T-DNA riorf13. In summary, T-DNA border fragments found were at eight independent sites of T-DNA integration, six borders of T-DNAs connected in tandem, and four borders connected with T-DNA internal fragments.

As for the copy numbers, types (A) and (B) corresponded to eight and six copies of T-DNAs, respectively. In the case of type (C), LB and $\mathrm{RB}$ connected with riorf13 were possibly borders of independent T-DNAs or borders of the same T-DNA. Therefore, the copy number can be estimated as two at minimum to four at maximum. Finally, the T-DNA copy number in the PsM1-2 $\mathrm{T}_{0}$ primary mutant could be estimated as 16 to 18 .

\subsection{Analysis of the Heredity Manner of T-DNA Inserted Loci}

The PCR analysis over T-DNA border and the adjacent genomic DNA found in the IPCR and AL-PCR analyses revealed that several T-DNA inserted loci were eliminated by selfing (Figure 6). 
Figure 6. Inheritance of the eight independent T-DNA insertion loci (RB1, RB2, RB3, RB4, RB5, LB2, LB3, and LB4) in the representative four lines of selfed progenies. (+: Insertion locus detected; -: insertion locus not detected.)

\begin{tabular}{c|c|cccccccc}
\hline \multirow{2}{*}{ Progenies } & \multirow{2}{*}{ Lines } & \multicolumn{7}{|c}{ T-DNA } \\
\cline { 2 - 9 } & & RB1 & RB2 & RB3 & RB4 & RB5 & LB2 & LB3 & LB4 \\
\hline $\mathrm{T}_{1}$ & $\# 1-27(\mathrm{HT})$ & + & + & - & - & + & + & + & + \\
\hline $\mathrm{T}_{2}$ & $\begin{array}{c}\# 1-27(\mathrm{HT}) \\
\text { L\#2 }\end{array}$ & + & + & - & - & + & + & + & + \\
\hline $\mathrm{T}_{3}$ & $\begin{array}{c}\# 1-27(\mathrm{HT}) \\
\text { L\#2 }\end{array}$ & + & + & - & - & + & + & + & + \\
\hline
\end{tabular}

\begin{tabular}{c|c|ccccccccc}
\hline \multirow{2}{*}{ Progenies } & \multirow{2}{*}{ Lines } & \multicolumn{7}{|c}{ T-DNA } \\
\cline { 3 - 9 } & & RB1 & RB2 & RB3 & RB4 & RB5 & LB2 & LB3 & LB4 \\
\hline $\mathrm{T}_{1}$ & $\# 2-17(\mathrm{HT})$ & + & - & + & - & + & + & + & + \\
\hline $\mathrm{T}_{2}$ & $\begin{array}{c}\# 2-17(\mathrm{HT}) \\
\# 2-1\end{array}$ & + & - & + & - & + & + & + & - \\
\hline $\mathrm{T}_{3}$ & $\# 2-17(\mathrm{HT})$ & + & - & + & & + & + & + & - \\
\hline
\end{tabular}

Line\#1-27(HT)

Line \#2-17(HT)

\begin{tabular}{|c|c|c|c|c|c|c|c|c|c|c|c|c|c|c|c|c|c|c|c|c|c|}
\hline & & & & & & & & & & & & & & & & & & & & & \\
\hline & & & & & & nenv & & & & T-D & NA & & & & & & & & & & \\
\hline & & & & & & ogeny & RB1 & RB2 & RB3 & RB4 & RB5 & LB2 & LB3 & LB4 & & & & & & & \\
\hline & & & & & & $T_{0}$ & + & + & + & + & + & + & + & + & & & & & & & \\
\hline Line & 2-1(LT & & & & & & & & & & & & & & & & & ine & $¥ 2-6$ & $5(\mathrm{~L}$ & \\
\hline Progrnies & Jines & & & & T-D & & & & & Pro & onis & & Iinec t & & & & T-D & NA & & & \\
\hline 1 10 gents & & RB1 & RB2 & RB3 & RB4 & RB5 & LB2 & LB3 & LB4 & & 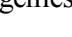 & & S & RB1 & RB2 & RB3 & RB4 & RB5 & LB2 & LB3 & LB4 \\
\hline $\mathrm{T}_{1}$ & \#2-1(LT) & + & - & + & - & + & + & + & - & & $\mathrm{T}_{1}$ & & $2-6(\mathrm{LT})$ & + & + & - & - & - & + & - & + \\
\hline $\mathrm{T}_{2}$ & $\begin{array}{c}\# 2-1(\mathrm{LT}) \\
\# 2-4\end{array}$ & + & - & + & - & + & + & + & - & & $\mathrm{T}_{2}$ & & $\begin{array}{l}2-6(\mathrm{LT}) \\
\# 2-2\end{array}$ & + & + & - & - & - & + & - & + \\
\hline
\end{tabular}

In the high thebaine line \#1-27(HT), of the eight loci that were suggested to be independent T-DNA integration sites, RB3 and RB4 were eliminated in $\mathrm{T}_{1}$ progeny; in addition, in the high thebaine line \#2-17(HT), RB2, RB4 were eliminated in $\mathrm{T}_{1}$ progeny and the additional elimination of LB4 was observed in $\mathrm{T}_{2}$ progeny. On the other hand, with respect to the LT lines that showed low thebaine content at $T_{1}$ progeny, sites RB2, RB4, and LB4 were eliminated in \#2-1(LT), and sites RB3, RB4, RB5, and LB3 were eliminated in \#2-6(LT).

Notably thebaine content in these LT lines increased again in the $\mathrm{T}_{2}$ progeny to $29.4 \%$ in \#2-1(LT)\#2-4 and to 21.1\% in \#2-6(LT)\#2-2 (Table 2) without a change in the T-DNA insertion pattern (Figure 6). These results imply that none of the eight T-DNA integrated loci were indispensable for the high thebaine phenotype.

\subsection{T-DNA Copy Number Analysis by Real-Time PCR}

Standard curves for the quantification of the T-DNA copy number in $\mathrm{T}_{0}$ and selected progenies were prepared for each target region, $\mathrm{LB} 1 \mathrm{~g}, \mathrm{LB} 1 \mathrm{j}$ and orf2. The formulae and correlation coefficients were as follows: LB1g: $y=-1.39 \ln (x)+23.82\left(r^{2}=0.991\right)$; $L B 1 j: y=-1.44 \ln (x)+23.38\left(r^{2}=0.994\right)$; and orf $2: y=-1.43 \ln (x)+23.75\left(r^{2}=0.997\right)$. The relative abundances of each region in the samples were calculated by these formulae from the value of Delta $\mathrm{Rn}$. The relative abundances in whole numbers, when the abundance of LB1g was set as 2, were LB1g:LB1j:orf2 = 2:1:15 in $\mathrm{T}_{0}$. And for $\mathrm{T}_{1}$ [\#1-27(HT)] and its progenies, the abundances were as follows (in the order of LB1g:LB1j:orf2): $\mathrm{T}_{1}$ [\#1-27(HT)], 2:2:6; $\mathrm{T}_{2}[\# 1-27(\mathrm{HT}) \mathrm{L} \# 2], 2: 2: 7 ;$ and $\mathrm{T}_{3}[\# 1-27(\mathrm{HT}) \mathrm{L} \# 2 \# 1], 2: 2: 7$. And for $\mathrm{T}_{1}[\# 2-17(\mathrm{HT})]$ and its progenies, the values were as follows: $\mathrm{T}_{1}[\# 2-17(\mathrm{HT})], 2: \mathrm{nd}: 10 ; \mathrm{T}_{2}[\# 2-17(\mathrm{HT}) \# 2-1]$, 2:nt:10; and $\mathrm{T}_{3}$ [\#2-17(HT)\#2-1\#1], 2:nt:7 (nd: not detected; nt: not tested). These results are summarized in Figure 7. 
Figure 7. Shift of the relative abundance of target regions LB1g, LB1j, and orf2 of T-DNA insertion locus LB1-RB2 analyzed for two selfed lines, \#1-27(HT) and \#2-17(HT) by quantitative real-time PCR.

Line \#1-27(HT)

\begin{tabular}{cccc}
\hline Progeny & $\begin{array}{c}\text { LB1g } \\
\text { genome }\end{array}$ & $\begin{array}{c}\text { LB1j } \\
\text { border }\end{array}$ & $\begin{array}{c}\text { orf2 } \\
\text { T-DNA }\end{array}$ \\
\hline $\mathbf{T}_{\mathbf{0}}$ & $\mathbf{2}$ & $\mathbf{1}$ & $\mathbf{1 5}$ \\
$\mathbf{T}_{\mathbf{1}}$ & $\mathbf{2}$ & $\mathbf{2}$ & $\mathbf{6}$ \\
$\mathbf{T}_{\mathbf{2}}$ & $\mathbf{2}$ & $\mathbf{2}$ & $\mathbf{7}$ \\
$\mathbf{T}$ & $\mathbf{2}$ & $\mathbf{2}$ & $\mathbf{7}$ \\
\hline
\end{tabular}

Line \#2-17(HT)

\begin{tabular}{cccc}
\hline Progeny & $\begin{array}{c}\text { LB1g } \\
\text { genome }\end{array}$ & $\begin{array}{c}\text { LB1j } \\
\text { border }\end{array}$ & $\begin{array}{c}\text { orf2 } \\
\text { T-DNA }\end{array}$ \\
\hline $\mathbf{T}_{\mathbf{0}}$ & $\mathbf{2}$ & $\mathbf{1}$ & $\mathbf{1 5}$ \\
$\mathbf{T}_{\mathbf{1}}$ & $\mathbf{2}$ & $\mathbf{n d}$ & $\mathbf{1 0}$ \\
$\mathbf{T}$ & $\mathbf{2}$ & $\mathbf{n t}$ & $\mathbf{1 0}$ \\
$\mathbf{T}$ & $\mathbf{2}$ & $\mathbf{n t}$ & $\mathbf{7}$ \\
\hline
\end{tabular}

The numbers in the column of orf2 represent the estimated copy number of T-DNA. (nd: Not detected; nt: not tested.) "Homo" indicates that the LB1-RB2 locus became homozygous at the $\mathrm{T}_{1}$ progeny in \#1-27(HT) and "eliminated" indicates that the LB1-RB2 locus was eliminated at the $\mathrm{T}_{1}$ progeny in $\# 2-17(\mathrm{HT})$.

For the abundance of $\mathrm{LBj}$ and orf2 in the \#1-27(HT) series, the LB1-RB2 T-DNA insertion locus was estimated to become homozygous at the $\mathrm{T}_{1}$ progeny, as indicated by the doubled abundance of LB1j in $T_{1}$. And the T-DNA copy number, estimated by the abundance of the orf 2 region, was drastically decreased from 15 to six in $T_{1}$, then increased to seven in $T_{2}$ and kept at seven in $T_{3}$. These data imply that more than half of the total T-DNA copies were eliminated in the first selfing. For the \#2-17 series, the LB1j region was not detected in $T_{1}$, which was consistent with the elimination of the LB1-RB2 $T$-DNA insertion loci in $T_{1}$ revealed by the T-DNA insertion loci analysis (Figure 6). The abundance of orf 2 was decreased from 15 to 10 in $T_{1}$, and then decreased again from 10 to seven in $T_{3}$, which implies that more than half of the T-DNA copies in the \#2-17(HT) series were also eliminated by repeated selfing.

\subsection{Expression Analyses on Morphine Biosynthetic Genes by RT-PCR}

Firstly we tried to apply realtime-PCR for the expression analysis of morphine biosynthetic genes including T6ODM, CODM using the primer sequence reported by Hagel and Facchini [10]. However, prior to run the realtime-PCR, we found that PCR with these primers using our cDNA as a template gave multiple products. Although we have designed several primers, they could not make the PCR product as a single band. It may be attributed to the relatively high sequence homology of coding region among T6ODM, CODM, and DIOX2. Therefore we hired the semi-quantitative RT-PCR method for the expression analysis. To distinguish RT-PCR products between T6ODM and CODM, primers were designed to give different product size, i.e., $549 \mathrm{bp}$ for T6ODM and $411 \mathrm{bp}$ for CODM.

Expression analysis on selected morphine biosynthetic genes downstream of $(S)$ - $N$-methylcoclaurine revealed that the expression of CODM was completely diminished in PsM1-2 (Figure 8). On the other hand, the expression of T6ODM seemed to be slightly up-regulated in the PsM1-2 compared with the WT plant. Specific amplification of these two genes was confirmed by the comparison of the size of the bands and their calculated amplicon size. In PsM1-2, the expression levels of CYP80B3 and SalAT 
seem to be slightly higher than WT, whereas $4^{\prime} O M T$ seems to be down-regulated. No significant difference in the expression level of genes was observed between PsM1-2 and WT for Cor 1-1 or Cor2-1.

Figure 8. The morphine biosynthetic pathway downstream of $(S)-N$-methylcoclaurine with the results of expression analysis of selected morphine biosynthetic genes, CYP80B3, 4'OMT, SalAT, T6ODM, COR (alleles Cor1-1 and Cor2-1), and CODM by RT-PCR. Actin was used as an experimental control. Presumably, the pathway via oripavine (dotted pathway) does not exist in the P. somniferum Japanese cultivar "Ikkanshu" which we have used in this study $[11,12]$.

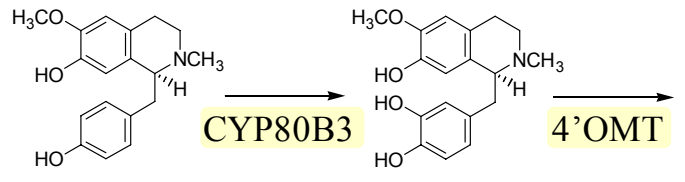

(S)- $N$-methylcoclaurine

(S)-3'-hydroxy- $N$-methylcoclaurine

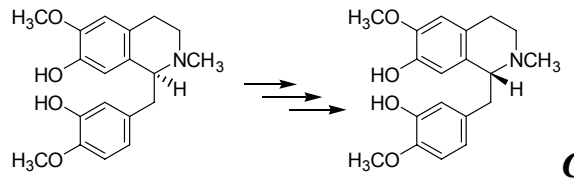

(S)-Reticuline
$(R)$-Reticuline

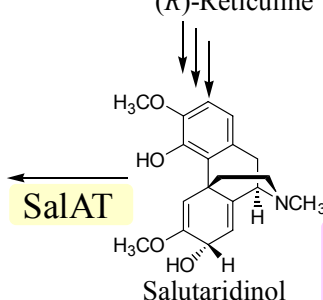

CYP80B3

WT PsM1-2

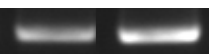

4'OMT

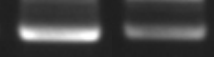

SalAT

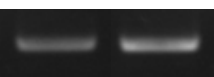

T6ODM

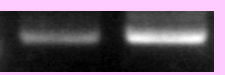

Cor1-1

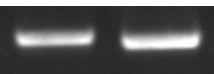

$\operatorname{Cor} 2-1$

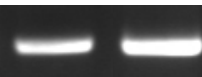

CODM

Actin

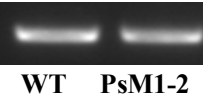

\subsection{Discussion}

Morphological abnormalities, such as varied numbers of petals and splits on the boundary of petals, were frequently observed in the selfed progenies in the present study. However, no clear correlation was found between these morphological abnormalities and altered alkaloid compositions. Therefore, these findings were thought to be independent of the mutation in the secondary metabolism.

At the $\mathrm{T}_{2}$ generation, difference between high thebaine line and low thebaine line which was obvious at $\mathrm{T}_{1}$ generation, has disappeared. If the high thebaine phenotype is cause by the single mutation of the locus by T-DNA insertion, low thebaine phenotype should be dominant in the progeny plants. However, as observed in Figure 3, most of the progeny plants of low thebaine $T_{1}$ lines have gained high thebaine phenotype again, which indicates that the multiple loci are responsible for the high thebaine phenotype. For the reason of this phenomenon, it is also possible that, methylation or suppression has occurred in unstable manner on the alkaloid biosynthesis related genes caused by the multiple T-DNA insertion events. 
The content of thebaine, which was the major alkaloid in the latex of the mature plants of the mutants, varied widely in the $T_{1}$ progeny. But by repeated selfing, in the $T_{3}$ progeny, although the maximum content of thebaine $(10.9 \%)$ was not particularly high, the range of thebaine content was much narrower than that in the $T_{1}$ and $T_{2}$ progenies. When the value of $\mathrm{CV}$ (coefficient of variation: standard deviation/average value) for the thebaine content was compared among $T_{1}, T_{2}$, and $T_{3}$ progenies, it was 0.54 in $\mathrm{T}_{1}, 0.40$ in $\mathrm{T}_{2}$ (two HT lines combined), and 0.26 in $\mathrm{T}_{3}$ (two lines combined). And the $\mathrm{CV}$ for the morphine content was 0.74 in $\mathrm{T}_{1}, 0.70$ in $\mathrm{T}_{2}$ (two HT lines combined), and 0.28 in $\mathrm{T}_{3}$ (two lines combined). These lines of evidence indicate that the high thebaine (2.4-fold and 2.5-fold of WT in $\mathrm{T}_{3} \# 1-27$ (HT)L\#2 and \#2-17(HT)\#2-1, respectively) and low morphine (0.2-fold of WT in both $\mathrm{T}_{3} \# 1-27$ (HT)L\#2 and \#2-17(HT)\#2-1, respectively) phenotypes were stabilized by repeated selfing.

Analyses of the T-DNA integration sites and T-DNA copy number on the primary $\mathrm{T}_{0}$ mutant revealed that at least eight integration sites exist and as many as 18 copies of T-DNAs were estimated to be integrated into the genomic DNA in a highly complicated manner. Considering the complexity of the T-DNA integration, the IPCR, AL-PCR, and real-time PCR methods employed in this study can be considered as the most suitable methods for T-DNA insertional analysis, and more suitable than Southern blotting, whose signals may be beyond interpretation in this context. The number of T-DNA copies in PsM1-2 was too large for the transgenes integrated by genetical transformation. The presence of high numbers of transgenic insertions can lead to poor expression of transgenes through silencing. In this study, we tried to simplify the T-DNA integration structure and stabilize the high thebaine phenotype, and then to gain insight into the genetic factors for the altered alkaloid composition by obtaining selfed progenies. The T-DNA integration sites in PsM1-2 were paired to be homozygous or dropped off by selfing, and finally became half of the $T_{0}$ in the selected $T_{3}$ progenies. Although it is possible that other T-DNA copies were not detected, no correlation was found between any of the T-DNA integration sites and the altered alkaloid composition, by considering these data together, a reduction in the T-DNA copy number seems to have resulted in the stabilization of the high thebaine phenotype. Although it is hard to confirm, there is also a possibility that genome reorganization independent of T-DNA insertion has occurred during shoot regeneration or long term maintenance of in vitro culture. As we have accomplished the stabilization of high thebaine phenotype by selfing up to $\mathrm{T}_{3}$ generation, backcross experiment utilizing these selfed progeny plants is in progress.

In this study, the only gene homologous to the known gene found at the T-DNA integration loci was the AtWRKY4 gene homologue found in the 5' upstream region of LB1g. As some type of WRKY transcription factor may function as a transcriptional regulator of benzylisoquinoline alkaloid biosynthesis in Coptis japonica Makino [13], the contribution of this locus to the altered alkaloid composition in the mutant was suspected. However, analysis of the T-DNA heredity manner indicated that the T-DNA insertion at LB1-RB2 region was not essential for the high thebaine phenotype.

The expression analyses on selected morphine biosynthetic genes, including two novel demethylases, T6ODM and CODM, between the in vitro shoot culture of the PsM1-2 mutant and seedlings of the WT plant revealed that the expression of CODM was fully suppressed in the mutant. Although the correlation between the transcript level of biosynthetic genes in young organs, such as seedling or in vitro shoot culture, and the alkaloid composition in the latex of mature plant needs to be clarified, the observed differences between the wild type plant and the mutant can be correlated to the alkaloid 
composition difference in them (morphine was detected in the WT, however, almost no morphine in the mutant [8]).

Kinetic studies on recombinant T6ODM and CODM from P. somniferum [10] have revealed that oripavine is the most preferred substrate of T6ODM, followed by thebaine, while codeine is not accepted as a substrate. On the other hand, CODM showed a higher preference for codeine than thebaine. Considering the substrate preference of these two demethylases, thebaine can be accumulated solely only under the condition that the expression of both T6ODM and CODM is suppressed, and the suppression of CODM may result in accumulation of codeine. In actuality, however, a large amount of thebaine with a smaller amount of codeine is accumulated in the latex from mature plants of PsM1-2 mutants. This pattern of compounds detected in the mutant is similar to that of the T6ODM-silenced transformant by virus-induced gene silencing [10]. In contrast, the CODM-silenced transformant accumulates mainly codeine, together with smaller amounts of thebaine and morphine [10]. Although the alkaloid productivities of those transformants cannot be simply compared with PsM1-2, as the alkaloid composition varies highly even among the cultivars [14], it is assumed that suppression of CODM did not simply lead to the thebaine accumulation in PsM1-2. And it is also possible that in a Japanese cultivar that does not have the pathway from thebaine to morphine via oripavine [11,12], the substrate preferences of T6ODM and CODM differ from those of oripavine-producing cultivars.

As the regulation of opium alkaloid production in $P$. somniferum is highly complicated and varies among cultivars - and even among the developmental stages $[15,16]$ or individual parts of a single plant [17] - further detailed studies on the molecular regulation of alkaloid production, such as expression analyses of T6ODM and CODM in the latex-producing capsule of PsM1-2, are required.

\section{Experimental Section}

\subsection{Plant Materials}

The wild type (WT) plant of P. somniferum L. used was the Japanese cultivar "Ikkanshu", and the A. rhizogenes strain MAFF03-01724 T-DNA insertion mutant line was PsM1-2 [8]. The in vitro culture of PsM1-2 used in this experiment was previously subjected to a single round of cryopreservation and regenerated to plantlet on Murashige-Skoog (MS) solid media [18] by the method described previously $[19,20]$ with slight modifications.

\subsection{Maintenance and Cultivation of Plant Materials}

The WT plant seeds were obtained from the field-grown plants at the Research Center for Medicinal Plant Resources, Division of Tsukuba.

The PsM1-2 $\mathrm{T}_{0}$ in vitro shoot culture was maintained on MS solid media at $20{ }^{\circ} \mathrm{C}$ under a $14 \mathrm{~h}$ light $/ 10 \mathrm{~h}$ dark condition and then transplanted in soil in a $9 \mathrm{~cm}$ diameter pot and acclimatized in a phytotron in $60 \%$ relative humidity under a cycle of $16 \mathrm{~h}$ light at $20^{\circ} \mathrm{C}$ and $8 \mathrm{~h}$ dark at $17{ }^{\circ} \mathrm{C}$.

Seeds of $\mathrm{T}_{1}$ plant obtained from the soil-cultivated plant of the PsM1-2 $\mathrm{T}_{0}$ primary mutant were sown on the soil in a $15 \mathrm{~cm}$ diameter pot and cultivated in a greenhouse under a $16 \mathrm{~h} \mathrm{light} / 8 \mathrm{~h}$ dark cycle at $20{ }^{\circ} \mathrm{C}$ and $60 \%$ relative humidity. Plants were fertilized with 500 -fold diluted Hyponex ${ }^{\circledR}$ (Hyponex Japan, Osaka, Japan) once a week. 
$\mathrm{T}_{2}$ seeds from the two lines of $\mathrm{T}_{1}$ plants that showed high thebaine content and had abundant mature seeds were selected for cultivation of $\mathrm{T}_{2}$ progeny. The cultivation conditions were the same as for $\mathrm{T}_{1}$ plants.

$\mathrm{T}_{3}$ seeds from two lines of $\mathrm{T}_{2}$ plants with high thebaine content were germinated on rock wool with fertilization with 2,000-fold diluted Hyponex ${ }^{\circledR}$ in a greenhouse under a $16 \mathrm{~h}$ light $/ 8 \mathrm{~h}$ dark cycle at $20{ }^{\circ} \mathrm{C}$ and $60 \%$ relative humidity. After one month, seedlings were transplanted onto the soil in a $9 \mathrm{~cm}$ diameter pot, and grown in the growth chamber under a $12 \mathrm{~h} \mathrm{light} / 12 \mathrm{~h}$ dark condition (short day condition) at $20^{\circ} \mathrm{C}$ and $60 \%$ relative humidity. $\mathrm{Ca}$. 80 days after sowing, the lighting was changed to a long day condition of $16 \mathrm{~h}$ light $/ 8 \mathrm{~h}$ dark at $20^{\circ} \mathrm{C}$ and $60 \%$ humidity for flowering. After transplanting, plants were fertilized with 500 -fold diluted Hyponex ${ }^{\circledR}$ once a week.

For each experiment, WT plants were grown together as an experimental control. All self-pollination events were performed manually.

\subsection{Phenotypic Observation of the PsM1-2 Mutants}

Phenotypic parameters such as days to flowering, number of petals, appearance of splitting on the boundary of the petal, and the height of the aerial part at the seed-filling stage, were observed on each plant.

\subsection{HPLC Analysis of Alkaloid Content in the Latex}

The opium alkaloid content in the latex was analyzed by HPLC. Latex was collected from the capsule of either the WT or mutant $P$. somniferum $c a$. two weeks after flowering, by incising the capsule surface. Collected latex was dried at $50{ }^{\circ} \mathrm{C}$. Approximately $5 \mathrm{mg}$ of dried latex was measured accurately and subjected to alkaloid extraction by adding $5 \mathrm{~mL}$ of methanol followed by $30 \mathrm{~min}$ of sonication and mixing thoroughly using a tube mixer. After centrifugation at $20,000 \times g$ for $1 \mathrm{~min}$, supernatant was applied to an Ultrafree-MC spin column (Millipore, Bedford, MA, USA) and centrifuged at $20,000 \times g$ for $1 \mathrm{~min}$, and then $5 \mu \mathrm{L}$ of the flow through was injected into an HPLC column. The HPLC conditions were as follows. HPLC instruments: Waters Alliance PDA System (separation module: 2795; photodiode array detector: 2996) (Waters, Milford, MA, USA). Column: TSK-GEL ODS100V (pore size $5 \mu \mathrm{m}, \phi 4.6 \times 250 \mathrm{~mm}$ ) (Tosoh, Tokyo, Japan). Solvent system: $\mathrm{CH}_{3} \mathrm{CN}$ (A),

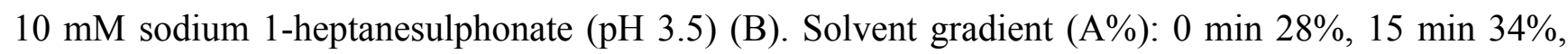
25 to $39 \mathrm{~min} 40 \%$, $40 \mathrm{~min} 28 \%$. Detection: UV 200 to $400 \mathrm{~nm}$ (spectrometric identification of compounds), UV $284 \mathrm{~nm}$ (quantitative analysis). Column temperature: $30{ }^{\circ} \mathrm{C}$. Flow rate: $0.7 \mathrm{~mL} / \mathrm{min}$. HPLC data were collected and analyzed by an Empower system (Waters).

Alkaloid components were identified by the comparison of retention time and the UV spectra with authentic standards. Morphine hydrochloride and codeine phosphate were purchased from Takeda Pharmaceutical Company Limited (Osaka, Japan). Oripavine was a gift from Einar Brochmann-Hanssen (University of California, San Francisco, CA, USA). Magnoflorine iodide and jateorrhizine were gifts from Akira Ikuta (Science University of Tokyo, Japan). Reticuline and columbamine were gifts from Fumihiko Sato (Kyoto University, Japan). Isothebaine was isolated from Papaver pseudo-orientale (Fedde) Medw. by our group. Thebaine was a gift from Ruri Kikura-Hanajiri (National Institute of Health Sciences, Japan). Papaverine hydrochloride, noscapine hydrochloride, coptisine chloride, sanguinarine chloride, and berberine chloride were purchased from Wako Pure Chemical Industries (Osaka, Japan). Alkaloid contents were calculated as a weight percent of the dried latex (opium). 


\subsection{Genomic DNA Preparation from P. somniferum}

Genomic DNA was prepared from $c a .100 \mu \mathrm{g}$ of fresh leaves of selfed plants grown in the growth chamber, or from $c a$. $100 \mu \mathrm{g}$ of whole in vitro plantlet of the PsM1-2 $\mathrm{T}_{0}$ mutant, which mainly consisted of leaves and stems, by using a DNeasy Plant Mini Kit (Qiagen, Hilden, Germany) according to the manufacturer's instructions.

\subsection{Analysis of T-DNA Insertion Loci by IPCR and AL-PCR}

The inverse-PCR (IPCR) method [21,22] and adaptor ligation PCR (AL-PCR) method were used for the analysis of the flanking unknown genome DNA sequence, adjacent to the inserted T-DNA. In this study, the Vectorette PCR method [23-25], an improved method of AL-PCR, was employed to reduce non-specific amplicons.

The genomic DNA library for each PCR method was constructed by digestion of genomic DNA by the appropriate restriction enzymes and self-ligation to form a circular DNA library, or an adaptor linker attached genome DNA library.

\subsection{Genomic Library Construction for IPCR}

Genomic DNA was digested with the restriction enzymes BamHI, EcoRV, HaeIII, KpnI, PvuII, $S s p \mathrm{I}$, or StuI. Completely digested DNA was ligated by using a Fastlink ${ }^{\circledR}$ DNA Ligation Kit (AR Brown, Tokyo, Japan) to form a circular genome DNA library.

\subsection{Genomic Library Construction for AL-PCR}

The sequences of the adaptor oligo DNA and adaptor specific primers used in this study are listed in Supplementary Table 2. Two complementary oligo DNAs, AP-LS and AP-SS, were annealed to form an adaptor unit. Genomic DNA was digested with the restriction enzymes EcoRV, HaeIII, PvuII, SspI, or $S t u$ I, which produce blunted ends. The completely digested DNA was ligated with adaptor units by using a Fastlink ${ }^{\circledR}$ DNA Ligation Kit to form an adaptor ligated genome DNA library.

\subsection{IPCR and $A L-P C R$}

Amplification of the target region was performed by the nested PCR method using TaKaRa Ex $\mathrm{Taq}^{\mathrm{TM}}$ DNA polymerase (Takara Bio, Shiga, Japan) under the following conditions. The combinations of PCR methods, template genome DNA libraries and primer sets are listed in Supplementary Table 1. T-DNA-specific primers were designed based on the DNA sequence of the T-DNA region of the A. rhizogenes plasmid pRi1724 (DDBJ/EMBL/GenBank accession no. AP002086). The first PCR conditions were as follows: primary denaturation at $94{ }^{\circ} \mathrm{C}$ for $5 \mathrm{~min}$; followed by 30 cycles of $94{ }^{\circ} \mathrm{C}$ for $1 \mathrm{~min}, 42^{\circ} \mathrm{C}$ for $2 \mathrm{~min}$, and $72{ }^{\circ} \mathrm{C}$ for $3 \mathrm{~min}$; with a final extension at $72{ }^{\circ} \mathrm{C}$ for $10 \mathrm{~min}$. After PCR, the solution was held at $4{ }^{\circ} \mathrm{C}$. The first PCR reaction solution was applied to a SUPREC ${ }^{\mathrm{TM}}-02$ filter (Takara Bio) to eliminate the primers and then used as a template for the second PCR. Second PCR conditions were as follows: primary denaturation at $94{ }^{\circ} \mathrm{C}$ for $5 \mathrm{~min}$; followed by 30 cycles of $94{ }^{\circ} \mathrm{C}$ for $1 \mathrm{~min}, 48^{\circ} \mathrm{C}$ for $2 \mathrm{~min}$, and $72{ }^{\circ} \mathrm{C}$ for $3 \mathrm{~min}$; with a final extension at $72{ }^{\circ} \mathrm{C}$ for $10 \mathrm{~min}$. After PCR, 
the solution was held at $4{ }^{\circ} \mathrm{C}$. The product of the second PCR was gel purified and cloned into the sequencing vector $\mathrm{pT7}-\mathrm{Blue}^{\circledR}$ (Novagen, Madison, WI). Propagated plasmid DNA was subjected to DNA sequencing using a BigDye ${ }^{\circledR}$ Terminator v3.1 Cycle Sequencing Kit and ABI PRISM ${ }^{\circledR} 3100$ - Avant Genetic Analyzer (Applied Biosystems Japan, Tokyo, Japan). Homology search was performed on T-DNA flanking genome DNA sequences with the BLAST tool at NCBI.

\subsection{Direct Amplification of T-DNA Borders Connected in Tandem}

PCR was performed on uncut genome DNA of $\mathrm{T}_{0}$ to amplify the border region of T-DNAs connected in tandem. The primers used are listed in Supplementary Table 1. The PCR conditions were the same as for the IPCR.

\subsection{Analyses of T-DNA Insertion Loci and Heredity Manner by PCR}

The PCR method was employed to confirm the T-DNA integration loci on P. somniferum genome DNA and to analyze the heredity manner in the selfed progenies.

To find out the tally of the paired genomic regions found adjacent to the T-DNA left borders (LBs) and right borders (RBs) revealed by IPCR and AL-PCR analyses, PCR amplification was performed with the pair of genomic region-specific LB and RB (e.g., LB1g vs. RB2g) primers listed in Supplementary Table 3, under the following PCR conditions: primary denaturation at $94{ }^{\circ} \mathrm{C}$ for $5 \mathrm{~min}$; followed by 30 cycles of $94{ }^{\circ} \mathrm{C}$ for $30 \mathrm{~s}, 58^{\circ} \mathrm{C}$ for $30 \mathrm{~s}$, and $72{ }^{\circ} \mathrm{C}$ for $1 \mathrm{~min}$; with a final extension at $72{ }^{\circ} \mathrm{C}$ for $10 \mathrm{~min}$. After PCR, the solution was held at $4{ }^{\circ} \mathrm{C}$. TaKaRa Ex Taq ${ }^{\mathrm{TM}}$ was used as the PCR polymerase. The PCR product was separated on agarose gel. The paired genomic regions, which gave a PCR product was judged as the single T-DNA integrated locus.

To judge whether or not the T-DNA integration loci were present in the selfed progenies, PCR amplification was performed between the genome region-specific primers listed in Supplementary Table 3 and T-DNA LB- or RB-specific primers (MAFF-226A or MAFF-14963S). PCR was performed under the following PCR conditions: primary denaturation at $94{ }^{\circ} \mathrm{C}$ for $5 \mathrm{~min}$; followed by 30 cycles of $94{ }^{\circ} \mathrm{C}$ for $30 \mathrm{~s}, 58^{\circ} \mathrm{C}$ for $30 \mathrm{~s}$, and $72{ }^{\circ} \mathrm{C}$ for $1 \mathrm{~min}$; with a final extension at $72{ }^{\circ} \mathrm{C}$ for $10 \mathrm{~min}$. After PCR, the solution was held at $4{ }^{\circ} \mathrm{C}$. GoTaq ${ }^{\circledR}$ Green Master Mix (Promega, Madison, WI, USA) was used as the PCR polymerase. The PCR product was separated on agarose gel.

\subsection{T-DNA Copy Number Analysis by Real-time PCR}

The T-DNA copy number was analyzed by the quantitative real-time PCR method [26,27]. The strategy used for estimating the T-DNA copy number is as follows. When information of one of the integrated T-DNA sites was provided by T-DNA integrated loci analysis, and also, when the T-DNA integrated site was a single copy, the copy number of the integrated T-DNA could be calculated as a multiple of the relative abundance of standard DNA fragments, as shown in Figure 9.

This estimation method can be enacted under the hypotheses that (1) the genome DNA of PsM1-2 is diploid $(2 \mathrm{n}=22)$ [28], (2) all of the T-DNA is integrated into the host genome DNA in a heterozygous manner, and (3) one of the integrated T-DNAs for which both the LB and RB borders are known (e.g., the LB1-RB2 locus) is a single copy. 
Under these hypotheses, by comparing the relative abundance of the T-DNA internal region (in this case, orf2), the T-DNA $-P$. somniferum genome junction region (LB1j), and the $P$. somniferum genome region (LB1g), we can calculate the inserted T-DNA copy number by fixing the abundance of LB1g as two.

Figure 9. Schematic diagram of the strategy of T-DNA copy number analysis by real-time PCR.

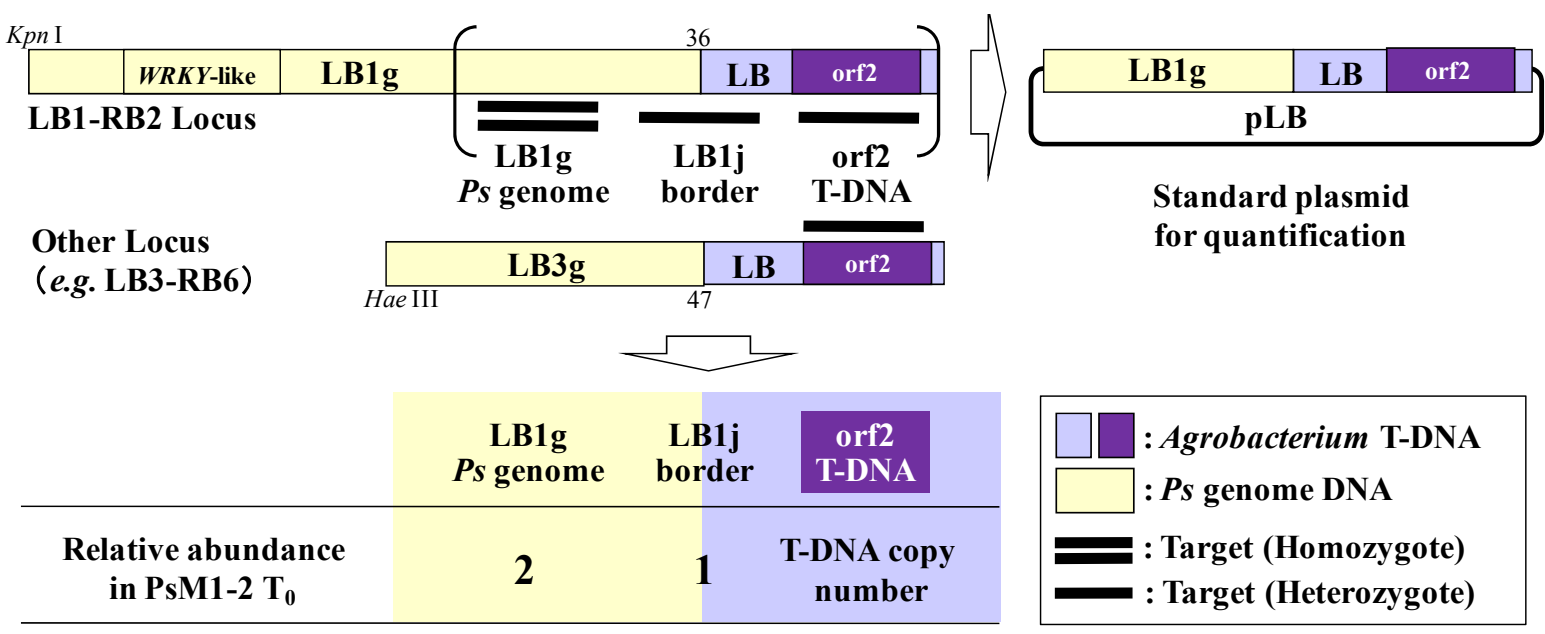

The LB1-RB2 locus whose LB and RB ends are confirmed was used as a standard. By setting the abundance of the genome DNA region (LB1g) of LB1 at a standard value of 2, the relative abundance of LB1j could be calculated as 1 . The relative abundance of the orf 2 region in the sample corresponded to the integrated T-DNA copy number. For the quantification, a standard plasmid pLB was constructed. "Ps genome" indicates the genome DNA of $P$. somniferum.

In our experiment, one of the T-DNA-integrated sites, LB1-RB2, which will be described in the Results section, was set as a standard. And for the quantification standard plasmid DNA, we constructed pLB1, which included, the LB1g, LB1j, and orf2 regions of the T-DNA. A DNA fragment with these three regions was amplified by PCR with the primers LB1-orf2-S (5'-CTC ATA AGC AGT GGT ATT GCT C-3') and LB1-orf2-A (5'-CGC ATT CAT GCG GTT ATG GAG-3') and KOD-Plus-DNA polymerase (Toyobo, Osaka, Japan) under the following PCR conditions: primary denaturation of $94{ }^{\circ} \mathrm{C}$ for $2 \mathrm{~min}$; followed by 35 cycles of $94{ }^{\circ} \mathrm{C}$ for $15 \mathrm{~s}, 62{ }^{\circ} \mathrm{C}$ for $30 \mathrm{~s}, 68{ }^{\circ} \mathrm{C}$ for $90 \mathrm{~s}$. After PCR, the solution was held at $4{ }^{\circ} \mathrm{C}$. The amplified product was cloned into the pT7-Blue ${ }^{\circledR}$ vector (Novagen) and then propagated in E. coli. The quantitative standard plasmid DNA pLB1 and genome DNA prepared from the primary $T_{0}$ mutant and selected $T_{1}, T_{2}$, and $T_{3}$ progenies of the PsM1-2 mutant were diluted serially with the dilution buffer supplied with the real-time PCR reagent $\mathrm{SYBR}^{\circledR}$ Premix Ex Taq ${ }^{\mathrm{TM}}$ II (Perfect Real Time; Takara Bio). Real-time PCR was run using the target region-specific primers listed in Supplementary Table 4 with the real-time PCR reagent on an ABI PRISM 7000 Sequence Detection System (Applied Biosystems Japan). The obtained data were analyzed using the supplied software (Applied Biosystems Japan) and the relative abundance of each target region was deduced from each Delta Rn value using standard curves. Standard curves for each target region were plotted with the plasmid concentration $(\mathrm{fg} / \mu \mathrm{L})$ on the $\mathrm{x}$-axis and the Delta $\mathrm{Rn}$ on the $\mathrm{y}$-axis. The curves showed good correlations. The relative abundances of each target region were calculated so that the abundance of the $\mathrm{LB} 1 \mathrm{~g}$ region was 2 , and then rounded off to a whole number. 


\subsection{Actin Gene Amplification from P. somniferum}

A fragment of actin cDNA was amplified by degenerate PCR using the forward primer 5'-AAR GCN AAY MGN GAR AAR ATG AC, and the reverse primer 5'-CCR TAN ARR TCY TTN CKD ATR TC, which were designed from the completely conserved regions of the amino acid sequences of other actins, such as Arabidopsis thaliana (actin-1: DDBJ/EMBL/GenBank accession No. M20016), Nicotiana tabacum (actin: X63603), and Zea mays (Maz56: U60514). cDNA synthesized from the total RNA of young seedlings of P. somniferum was used as a template for PCR. The manual hot-start procedure was used for the amplification. TaKaRa Ex $\mathrm{Taq}^{\mathrm{TM}}$ DNA polymerase was added after primary denaturation at $94{ }^{\circ} \mathrm{C}$ for $5 \mathrm{~min}$, and then the following protocol was carried out in a GeneAmp2400 thermal cycler (Applied Biosystems Japan): 30 cycles of $94{ }^{\circ} \mathrm{C}$ for $1 \mathrm{~min}, 48{ }^{\circ} \mathrm{C}$ for $2 \mathrm{~min}$, and $72{ }^{\circ} \mathrm{C}$ for $3 \mathrm{~min}$; with a final extension at $72{ }^{\circ} \mathrm{C}$ for $10 \mathrm{~min}$. After PCR, the solution was held at $4{ }^{\circ} \mathrm{C}$. The amplified fragment was cloned into the pT7-Blue ${ }^{\circledR}$ vector followed by DNA sequencing. Two representative actin cDNA sequences, whose deduced amino acid sequences showed $92 \%$ and $95 \%$ identity to the Arabidopsis actin-1, were named PSACT1 (AB574417) and PSACT2 (AB574418), respectively.

\subsection{Expression Analysis of the Morphine Biosynthetic Genes}

The expression levels of selected morphine biosynthetic genes downstream of $(S)-N$-methylcoclaurine, CYP80B3 (DDBJ/EMBL/GenBank accession no. AF134590 [29]), $(R, S)-3$ '-hydroxy- $N$-methylcoclaurine 4'-O-methyltransferase (4'OMT; AY217333 [15]), SalAT (AF339913 [30]), T6ODM (GQ500139 [10]), COR (allele Cor 1-1: AF108432; allele Cor2-1: AF108438 [31]), and CODM (GQ500141 [10]) in the WT plant and the PsM1-2 mutant were analyzed and compared by the reverse transcription PCR (RT-PCR) method.

Total RNA was prepared from the whole plants of two-week-old seedlings of field-grown WT $P$. somniferum, or from whole in vitro plantlet of the PsM1-2 $\mathrm{T}_{0}$ mutant, which mainly consisted of leaves and stems, by using an RNeasy Plant Mini Kit (Qiagen) according to the manufacturer's instructions. One microgram of total RNA samples was subjected to single-stranded cDNA synthesis by reverse-transcription with oligo-(dT) primer (RACE32: 5'-GAC TCG AGT CGA CAT CGA TTT TTT TTT TTT TT-3') [32] using Superscript ${ }^{\circledR}$ II Reverse Transcriptase (Life Technologies, Carlsbad, CA, USA) according to the manufacturer's instructions. Synthesized ss-cDNA was used as a template for PCR with the gene-specific primers listed in Supplementary Table 5. The PCR conditions were as follows: primary denaturation $94{ }^{\circ} \mathrm{C}$ for $5 \mathrm{~min}$; followed by 30 cycles of $94{ }^{\circ} \mathrm{C}$ for $30 \mathrm{~s}, 58{ }^{\circ} \mathrm{C}$ for $30 \mathrm{~s}$, and $72{ }^{\circ} \mathrm{C}$ for $1 \mathrm{~min}$; with a final extension at $72{ }^{\circ} \mathrm{C}$ for $10 \mathrm{~min}$. After PCR, the solution was held at $4{ }^{\circ} \mathrm{C}$. PCR products were separated on $1.0 \%$ agarose gel and signal intensities were observed. The actin gene PSACT1 from P. somniferum was used as an experimental control.

\subsection{Statistical Analysis}

Values were expressed as the mean \pm standard deviations (SD) and were analyzed by the Tukey-Kramer multiple comparison test using the statistical analysis system " $\mathrm{R}$ " software package [33]; a $p$ value of less than 0.05 was considered significant. 


\section{Conclusions}

By combining genetic and phenotypic analyses of the T-DNA insertional mutant PsM1-2 with selfing, we have succeeded in stabilizing the high thebaine phenotype in coordination with a reduction in the number of inserted T-DNA copies. Although the genetic mode of CODM suppression in in vitro plantlet and of the accumulation of thebaine still remain unknown, studies on this mutant and its progenies may provide new insights into the molecular basis of morphine biosynthesis, and could ultimately allow us to manipulate the biosynthesis of this compound at will.

\section{Acknowledgments}

We thank Naoko Tanaka and Naoko Onodera for their technical assistance. This study was supported in part by a grant from the Ministry of Health, Labor and Welfare of Japan.

\section{Conflict of Interest}

The authors declare no conflict of interest.

\section{References}

1. Frick, S.; Chitty, J.A.; Kramell, R.; Schmidt, J.; Allen, R.S.; Larkin, P.J.; Kutchan, T.M. Transformation of opium poppy (Papaver somniferum L.) with antisense berberine bridge enzyme gene (anti-bbe) via somatic embryogenesis results in an altered ratio of alkaloids in latex but not in roots. Transgenic Res. 2004, 13, 607-613.

2. Allen, R.S.; Millgate, A.G.; Chitty, J.A.; Thisleton, J.; Miller, J.A.C.; Fist, A.J.; Gerlach, W.L.; Larkin, P.J. RNAi-mediated replacement of morphine with the nonnarcotic alkaloid reticuline in opium poppy. Nat. Biotechnol. 2004, 22, 1559-1566.

3. Larkin, P.J.; Miller, J.A.; Allen, R.S.; Chitty, J.A.; Gerlach, W.L.; Frick, S.; Kutchan, T.M.; Fist, A.J. Increasing morphinan alkaloid production by over-expressing codeinone reductase in transgenic Papaver somniferum. Plant Biotechnol. J. 2007, 5, 26-37.

4. Frick, S.; Kramell, R.; Kutchan, T.M. Metabolic engineering with a morphine biosynthetic P450 in opium poppy surpasses breeding. Metab. Eng. 2007, 9, 169-176.

5. Allen, R.S.; Miller, J.A.; Chitty, J.A.; Fist, A.J.; Gerlach, W.L.; Larkin, P.J. Metabolic engineering of morphinan alkaloids by over-expression and RNAi suppression of salutaridinol 7-O-acetyltransferase in opium poppy. Plant Biotechnol. J. 2008, 6, 22-30.

6. Kempe, K.; Higashi, Y.; Frick, S.; Sabarna, K.; Kutchan, T.M. RNAi suppression of the morphine biosynthetic gene salAT and evidence of association of pathway enzymes. Phytochemistry 2009, 70, 579-589.

7. Millgate, A.G.; Pogson, B.J.; Wilson, I.W.; Kutchan, T.M.; Zenk, M.H.; Gerlach, W.L.; Fist, A.J.; Larkin, P.J. Analgesia: Morphine-pathway block in top1 poppies. Nature 2004, 431, 413-414.

8. Yoshimatsu, K.; Shimomura, K. Transformation of opium poppy (Papaver somniferum L.) with Agrobacterium rhizogenes MAFF 03-01724. Plant Cell Rep. 1992, 11, 132-136. 
9. Yoshimatsu, K.; Tono, K.; Shimomura, K. Cryopreservation of Medicinal Plant Resources-Retention of Biosynthetic Capabilities in Transformed Cultures. In Proceedings of the Japan International Research Center for Agricultural Sciences (JIRCAS)/International Plant Genetic Resources Institute (IPGRI) Joint International Workshop, Tsukuba, Japan, 20-23 October 1998; pp. S1-S6.

10. Hagel, J.M.; Facchini, P.J. Dioxygenases catalyze the $O$-demethylation steps of morphine biosynthesis in opium poppy. Nat. Chem. Biol. 2010, 6, 273-275.

11. Nielsen, B.; Röe, J.; Brochmann-Hanssen, E. Oripavine-A new opium alkaloid. Planta Med. 1983, 48, 205-206.

12. Brochmann-Hanssen, E. A second pathway for the terminal steps in the biosynthesis of morphine. Planta Med. 1984, 50, 343-345.

13. Kato, N.; Dubouzet, E.; Kokabu, Y.; Yoshida, S.; Taniguchi, Y.; Dubouzet, J.G.; Yazaki, K.; Sato, F. Identification of a WRKY protein as a transcriptional regulator of benzylisoquinoline alkaloid biosynthesis in Coptis japonica. Plant Cell Physiol. 2007, 48, 8-18.

14. Frick, S.; Kramell, R.; Schmidt, J.; Fist, A.J.; Kutchan, T.M. Comparative qualitative and quantitative determination of alkaloids in narcotic and condiment Papaver somniferum cultivars. J. Nat. Prod. 2005, 68, 666-673.

15. Facchini, P.J.; Park, S.-U. Developmental and inducible accumulation of gene transcripts involved in alkaloid biosynthesis in opium poppy. Phytochemistry 2003, 64, 177-186.

16. Yoshikawa, T.; Furuya, T. Morphinan alkaloid production by tissues differentiated from cultured cells of Papaver somniferum (1). Planta Med. 1985, 51, 110-113.

17. Weid, M.; Ziegler, J.; Kutchan, T.M. The roles of latex and the vascular bundle in morphine biosynthesis in the opium poppy, Papaver somniferum. Proc. Natl. Acad. Sci. USA 2004, 101, 13957-13962.

18. Murashige, T.; Skoog, F. A revised medium for rapid growth and bioassays with tobacco tissue cultures. Physiol. Plant 1962, 15, 473-497.

19. Yoshimatsu, K.; Yamaguchi, H.; Shimomura, K. Traits of Panax ginseng hairy roots after cold storage and cryopreservation. Plant Cell Rep. 1996, 15, 555-560.

20. Yoshimatsu, K.; Shimomura, K. Cryopreservation of Panax (Ginseng). In Biotechnology in Agriculture and Forestry 50, Cryopreservation of Plant Germplasm II; Towill, L.E., Bajaj, Y.P.S., Eds.; Springer-Verlag: Berlin/Heidelberg, Germany, 2002; pp. 164-179.

21. Ochman, H.; Gerber, A.S.; Hartl, D.L. Genetic applications of an inverse polymerase chain reaction. Genetics 1988, 120, 621-623.

22. Fladung, M. Gene stability in transgenic aspen (Populus). I. Flanking DNA sequences and T-DNA structure. Mol. Gen. Genet. 1999, 260, 574-581.

23. Arnold, C.; Hodgson, I.J. Vectorette PCR: A novel approach to genomic walking. PCR Methods Appl. 1991, 1, 39-42.

24. Spertini, D.; Beliveau, C.; Bellemare, G. Screening of transgenic plants by amplification of unknown genomic DNA flanking T-DNA. Biotechniques 1999, 27, 308-314.

25. Zheng, S.J.; Henken, B.; Sofiari, E.; Jacobsen, E.; Krens, F.A.; Kik, C. Molecular characterization of transgenic shallots (Allium cepa L.) by adaptor ligation PCR (AL-PCR) and sequencing of genomic DNA flanking T-DNA borders. Transgenic Res. 2001, 10, 237-245. 
26. Bubner, B.; Baldwin, I.T. Use of real-time PCR for determining copy number and zygosity in transgenic plants. Plant Cell Rep. 2004, 23, 263-271.

27. Yang, L.; Ding, J.; Zhang, C.; Jia, J.; Weng, H.; Liu, W.; Zhang, D. Estimating the copy number of transgenes in transformed rice by real-time quantitative PCR. Plant Cell Rep. 2005, 23, 759-763.

28. Levy, A.; Milo, J. Genetics and breeding of Papaver somniferum. In Poppy: The Genus Papaver; Bernáth, J., Ed.; Harwood Academic Publishers: Chur, Switzerland, 1998; pp. 93-103.

29. Huang, F.-C.; Kutchan, T.M. Distribution of morphinan and benzo[c]phenanthridine alkaloid gene transcript accumulation in Papaver somninferum. Phytochemistry 2000, 53, 555-564.

30. Grothe, T.; Lenz, R.; Kutchan, T.M. Molecular characterization of the salutaridinol 7-O-acetyltransferase involved in morphine biosynthesis in opium poppy Papaver somniferum. J. Biol. Chem. 2001, 276, 30717-30723.

31. Unterlinner, B.; Lenz, R.; Kutchan, T.M. Molecular cloning and functional expression of codeinone reductase: The penultimate enzyme in morphine biosynthesis in the opium poppy Papaver somniferum. Plant J. 1999, 18, 465-475.

32. Frohman, M.A.; Dush, M.K.; Martin, G.R. Rapid production of full-length cDNAs from rare transcripts: Amplification using a single gene-specific oligonucleotide primer. Proc. Natl. Acad. Sci. USA 1988, 85, 8998-9002.

33. The R Project for Statistical Computing. Available online: http://www.r-project.org/ (accessed on 15 January 2012).

(C) 2012 by the authors; licensee MDPI, Basel, Switzerland. This article is an open access article distributed under the terms and conditions of the Creative Commons Attribution license (http://creativecommons.org/licenses/by/3.0/). 